\title{
The Relationship of Metabolic Parameters with Serum Uric Acid and Percentage of Body Fat in Obese Adolescents
}

\author{
Obez Adölesanlarda Metabolik Parametreler ile Vücut Yağ Oranı ve \\ Serum Ürik Asit Düzeyi llişkisi
}

Nurullah ÇELIK, Aysun BIDECI, Hamdi Cihan EMEKSiZ, Esra DÖĞER, Özge YÜCE, Orhun ÇAMURDAN, Peyami CINAZ

Gazi University, Faculty of Medicine, Department of Child Health and Diseases, Pediatric Endocrinology Clinic, Ankara, Turkey

\begin{abstract}
Objective: To evaluate the relationship of metabolic parameters with serum uric acid and percentage of body fat in obese adolescents.

Material and Methods: A total 124 adolescents between 10-16 years of age were included in the study. Two groups were created as normal weight (Control, $n=40)$ and obese $(n=84)$. The obese children were also divided into 2 groups according to the presence or absence of Metabolic Syndrome (MS); Obese MS (-) $(n=45)$ and Obese MS (+) $(n=39)$. Bioelectrical impedance analysis was used to measure the percentage of body fat (BF \%).

Results: The values of body mass index- standard deviation score (BMI-SDS), waist circumference (WC), total body fat-standard deviation score (BF\% -SDS), systolic and diastolic blood pressure (BP), fasting insulin, HOMA-IR, triglyceride, $\mathrm{HDL}$ and uric acid were significantly different as expected $(p<0.001)$, whereas the fasting blood glucose, total cholesterol and $L D L$ values were similar $(p=0.41, p=0.70$ and $p=0.28$, respectively). Percentage of total body fat - standard deviation score and uric acid was significantly correlated with body BMI-SDS, waist circumference (WC), systolic and diastolic BP, fasting insulin, HOMA-IR, triglyceride and $\mathrm{HDL}(\mathrm{p}<0.001)$. In the multiple linear regressions, it was demonstrated that BF\%-SDS was significantly related to the systolic BP $(p<0.005)$, WC $(p<0.001)$ and uric acid $(\mathrm{p}<0.005)$.
\end{abstract}

Conclusion: Total body fat measured via bioelectrical impedance analysis and uric acid had a close relationship with MS components and may be a useful predictive marker for MS diagnosis.

Key Words: Bioelectrical impedance analysis, Body fat percentage, Metabolic syndrome, Uric acid

\section{ÖZET}

Amaç: Obez adölesanlarda total vücut yağ oranı ve serum ürik asit düzeyinin metabolik parametreler ile olan ilişkisini araştırmak.

Gereç ve Yöntemler: Çalışmaya yaşları 10-16 yıl olan 124 adölesan alındı. Normal tartılıar (Kontrol grubu, $n=40$ ) ve obezler (Çalışma grubu, $n=84$ ) olmak üzere iki grup oluşturuldu. Obez çocuklarda Metabolik Sendrom (MS) olup olmamasına göre, Obez MS (-) ( $n=45)$ ve Obez MS (+) ( $n=39)$ olmak üzere 2 gruba ayrıldı. Vücut yağ oranı (VYO) biyoelektrik impedans analizi ile ölçüldü.

Bulgular: Obez grupla kontrol grubu karşılaştırldığında Vücut Kitle İndeksi-Standart Deviasyon Skoru (VKI-SDS), bel çevresi (BÇ), vücut yağ oranı-SDS, sistolik ve diyastolik kan basıncı, açlık insülin, HOMA-IR değeri, ürik asit düzeyi, trigliserid ve HDL düzeyleri farklı iken ( $p<0.001$ ), açılık kan şekeri total kolesterol ve LDL düzeyleri benzerdi $(p=0.41 ; p=0.70$ and $p=0.28$ sırası ile). VYO-SDS ve serum ürik asit düzeyi ile VKI, bel çevresi, kan basıncı, kan şekeri, insülin, HOMA-IR değeri, trigliserid arasında pozitif, $\mathrm{HDL}$ arasında negatif korelasyon vardı $(p<0.001)$. Çoklu lineer regresyon analizinde VYO-SDS düzeyleri sistolik kan basıncı $(p<0.005)$, BÇ $(p<0.001)$ ve ürik asit $(p<0.005)$ düzeyi ile ilişkili bulundu.

Sonuç: Biyoelektrik impedans analizi ile ölçülen vücut yağ oranı ölçümü ve serum ürik asit düzeyi MS kompenentleri ile yakın ilişkili olup MS tanısında öngördürücü belirteç olarak kullanılabilirler.

Anahtar Sözcükler: Biyoelektrik impedans analizi, Vücut yağ oranı, Metabolik sendrom, Ürik asit

Correspondence Address / Yazışma Adresi:

Nurullah ÇELIK

Gazi Üniverstesi, Tıp Fakültesi, Çocuk Sağı̆̆ı ıe Hastalıkları Anabilim Dalı, Çocuk Endokrinoloji Bilim Dalı, Ankara, Türkiye

E-mail: celiknurullah@hotmail.com
Received / Geliş tarihi : 30.05 .2015 Accepted / Kabul tarihi : 29.06.2015

Online published 03.11 .2015

Elektronik yayın tarihi

DOI: 10.12956/tjpd.2015.188 


\section{INTRODUCTION}

The prevalence of obesity and Metabolic Syndrome (MS) among children has increased in recent years. Early recognition of children at risk of developing MS and subsequent progression to type 2 diabetes and cardiovascular disease in later life has become more important (1).

The amount of total body fat and its distribution for the evaluation of obesity is much more important than the body weight alone. Nowadays, many methods are used in the measurement of body fat distribution. Multi-compartment models, underwater weighing, air displacement plethysmography, labeled water techniques and dual-energy $X$-ray absorptiometry (DXA) are the most reliable methods in obtaining accurate measures of the total body fat (2). On the other hand, bioelectrical impedance is the most widely used method when the population size is big and a rapid measurement is required (3).

There is a strong correlation between body mass index (BMI) and percent body fat $(4,5)$. Total fat mass plays a crucial role in the development of the metabolic complications (6). This association is well known in adults $(7,8)$. However, only a few studies have been carried out with regard to the association of percentage of body fat (BF \%) and the components for MS in children and adolescents (6, 9-11)

Uric acid (UA) is produced from xanthine as the last product of purine metabolism by the action of the enzyme xanthine oxidase (12). Increased serum UA (s-UA) levels depend either on the excess production of uric acid or develop due to inadequate renal excretion. In previous studies conducted on children and adults, the close relationship between the uric acid level and MS has been demonstrated (13-16). However, there are contrary studies in literature reporting no reasonable relationship between s-UA levels and cardiovascular diseases, which is a consequence of MS (17).

The aim of this study was to evaluate the relationship between MS components and the percentage of BF measured via bioelectrical impedance analysis, and uric acid.

\section{METHODS}

\section{Study Design and Patient Selection}

This study was conducted by the Pediatric Endocrinology Department of Gazi University Hospital. The parents of all patients aged between 10-16 years who had been brought to the outpatient clinic were approached regarding the inclusion of their children in the study. A total 124 adolescents were included in the study. Two groups were created as normal weight (Control, $n=40)$ and obese $(n=84)$. Obese children were divided into 2 groups according to the presence or absence of MS; Obese MS (-) $(n=45)$ and Obese MS (+) $(n=39)$. All patients were subjected to a careful physical examination. The weights were measured using a calibrated digital scale, whereas the heights were measured in triplicate to the nearest millimeter using a calibrated stadiometer. The abdominal circumference, midway between the lowest rib and the top of the iliac crest at the end of expiration was measured to obtain the waist circumference (WC) (18). Blood pressure measurements were made with a sphygmomanometer cuff suitable for arm circumference, in the seated position, two times with an interval of two minutes, and the average measurements were recorded. The bioelectrical impedance analysis (Tanita TBF 300, TANITA Corp., Tokyo, Japan) was used to measure the BF according to a standard procedure described earlier. Percentage of body fat-SDS was calculated using the tables developed for Turkish children (19). Body mass indexes were calculated according to the formula [weight $(\mathrm{kg}) /$ height $\left.(\mathrm{m})^{2}\right]$. Patients with a history of a chronic disorder or on any medication that could alter the glucose metabolism and those with secondary obesity were excluded from the study. The institutional ethics committee approved the study protocol.

\section{DEFINITIONS}

Based on the MS criteria proposed by the International Diabetes Federation (IDF), the patients were diagnosed as having MS when their waist circumference was $\geq 90^{\text {th }}$ percentile and when at least two of the following factors were present (1):

(1) Increased fasting plasma glucose concentration of higher than $100 \mathrm{mg} / \mathrm{dL}$ or known T2DM.

(2) Increased concentration of triglycerides: $\geq 150 \mathrm{mg} / \mathrm{dL}$

(3) Decreased concentration of HDL cholesterol: $<40 \mathrm{mg} / \mathrm{dL}$

(4) Increased BP: Systolic BP $\geq 130 \mathrm{mmHg}$ or diastolic BP $\geq 85$ $\mathrm{mmHg}$.

\section{Biochemical Measurements}

Venous blood samples were obtained from all of the patients from the antecubital region between 8.00 and 8.30 am after an 8-12 hour overnight fast. Glucose, HDL, LDL, cholesterol, triglyceride and uric acid levels were measured with the spectrophotometric method using the autoanalyzer Olympus AU 2700 (Beckman Coulter Inc); the insulin levels were measured with the chemiluminescence method using the autoanalyzer Architect i2000sr (Abbott). Insulin resistance for each patient was estimated by the homeostatic model assessment method (HOMA-IR) using the formula [HOMA-IR= (glucose $\mathrm{X}$ insulin)/405].

\section{Statistical Analysis}

Statistical analysis was performed using the SPSS 13.0 for Windows (SPSS, Inc., Chicago, IL, USA). Comparisons of the variables with the normal distribution were carried out using the One-way ANOVA. The Pearson's Chi-square and the 
Fisher Exact tests were used for comparisons of the categorical variables, whereas the correlations between two variables were evaluated using the Pearson's correlation coefficient. The interactions between the body fat percentage and the various metabolic marker variables (systolic BP, diastolic BP, HOMA-IR, triglyceride, HDL and uric acid) were tested using multiple regression models. The values for all parameters, except gender, were expressed as mean \pm standard deviation, and a p-value of $<0.05$ was considered indicative of statistical significance.

\section{RESULTS}

The mean ages of controls ( $n=40), M S(-)$ obese subjects $(n=45)$ and $M S(+)$ obese subjects $(n=39)$ were similar $(13.3 \pm 2,13.2 \pm 2$ and 13.3 \pm 1.1 years, respectively, $p=0.92)$. All the groups were also similar according to their sex and pubertal status $(p=0.48$ and $p=0.99$, respectively). The values of BMI, BMI-SDS, WC, $\mathrm{BF} \%$, BF \% -SDS, systolic and diastolic BP, fasting insulin, HOMA-IR, triglyceride, HDL and uric acid were significantly different as expected $(p<0.001)$, whereas the fasting blood glucose, total cholesterol and LDL values were similar $(p=0.41$, $p=0.70$ and $p=0.28$, respectively). The baseline metabolic and anthropometric characteristics of the study population have been presented in Table I.

When the correlation between BF\%-SDS and the MS components were evaluated, there was a positive correlation between BF\%-SDS and BMI, BMI-SDS, WC, systolic and diastolic BP, fasting insulin, HOMA-IR, triglyceride and uric acid, and a negative correlation with HDL $(p<0.001)$. However, there was no correlation between BF\%-SDS and fasting blood glucose, total cholesterol and LDL (p>0.05) (Table II).

Similarly, on evaluation of the correlation between uric acid and the MS components; there was a positive correlation between uric acid, and BMI, BMI-SDS, BF\%, BF\%-SDS, WC, systolic and diastolic BP, fasting insulin, HOMA-IR triglyceride, and a negative correlation with HDL $(p<0.001)$. However, there was no correlation between uric acid and fasting blood glucose, total cholesterol and LDL ( $p>0.05)$ (Table II).

A multiple regression analysis was carried out with BF\%-SDS as the dependent variables, and BMI-SDS, waist circumference, systolic pressure, diastolic pressure, HDL, triglyceride, UA, IR as the independent variables. It was demonstrated that BF\%SDS was significantly related to the systolic BP, WC and UA (B $p<0.005, p<0.001 ; p<0.005$, respectively) (Table III).

\section{DISCUSSION}

We found that total body fat measured via bioelectrical impedance analysis had a close relationship with MS components that can be attributed to a modified adipokine secretion due to increased total body fat. We also demonstrated a positive correlation between uric acid and MS components.
There are limitations in the use of BMl as a measure of adiposity for the pediatric population, due to variation in BMl with age, sex, puberty and race or ethnicity $(20,21)$. It has also been reported that $\mathrm{BMI}$ has a low sensitivity to determine the degree of adiposity (11). Waist circumference (WC) as a measure of abdominal obesity is one of the criteria used for definition of MS (1). The main reason for using WC as an indicator of obesity in the 10-16-year age group in the IDF consensus report is its strong correlation with visceral adiposity $(1,22)$. However, there are contrary reports in children that waist circumference is not a reliable predictor in measuring abdominal obesity (23, 24). Measurement of BF percentage by bioelectrical impedance analysis may be more accurate than BMI and WC and constitute a feasible method in the determination of total body fat as a criterion of MS.

There are many studies in the literature investigating the relationship between body fat and metabolic components in adults $(7,8)$. However, only a few studies have been conducted on this subject in childhood and adolescence $(6,9-11)$. The measurement methods and compartments of the measured body fat (total (TFM), visceral (VFM), subcutaneous (SCFM) varied in these studies. We measured the total body fat rate using bioelectrical impedance analysis. To the best of our knowledge, this is the first study to evaluate the relationship between MS components and total body fat rates measured by bioelectrical impedance analysis. Furthermore, this is also the first study in which the total body fat rate is presented as SDS.

We determined a statistically significant correlation between BF\% and the MS components (BMI-SDS, WC, BP, HOMA-IR, Triglyceride, HDL, Uric acid). Two different studies conducted with Korean children have similarly found a relationship between the visceral fat rate measured with CT and the MS criteria $(9,10)$. Kim at al. (9) found that visceral fat was independently associated with the BP, blood triglyceride, blood HDL-C, FBG and HOMA-IR level. In their study in which they measured the body fat compartments separately, Druet at al. (6) determined that the body fat rate was associated with the total insulin resistance while the visceral fat rate was associated with MS.

The reason S-UA levels are high in MS is not yet clarified. The studies conducted on this issue have suggested various pathogenetic mechanisms: Facchini et al. (25) demonstrated that the urinary uric acid clearance was decreased in healthy individuals with high insulin resistance. Furthermore, some authors have demonstrated that leptin, which is at high levels in obese individuals, increases the renal re-absorption of uric acid (26). It has also been demonstrated that increased fructose consumption in obese individuals contributes to the increase of uric acid levels (27). In their study conducted with 4073 individuals, Gao et al. (28) reported that a higher consumption of sweetened foods in daily nutrition was associated with high s-UA levels.

Large epidemiological studies have demonstrated that the frequency of MS increases in parallel with increasing s-UA levels 
Table I: Baseline metabolic and anthropometric characteristics of the study population.

\begin{tabular}{|c|c|c|c|c|}
\hline & $\begin{array}{l}\text { Control Group } \\
(n=40)\end{array}$ & $\begin{array}{c}\text { Obese MS (-) } \\
\quad(n=45)\end{array}$ & $\begin{array}{c}\text { Obese MS (+) } \\
(n=39)\end{array}$ & $\mathbf{p}$ \\
\hline Age, Years (mean $\pm S D)$ & $13.3 \pm 2$ & $13.2 \pm 2$ & $13.3 \pm 1.1$ & NS \\
\hline Gender (female, \%) & 60.0 & 66.6 & 53.8 & NS \\
\hline Puberty (Tanner Stage) & $3.45 \pm 1.5$ & $3.44 \pm 1.5$ & $3.49 \pm 1.5$ & NS \\
\hline BMI & $18.5 \pm 2.7$ & $31.2 \pm 4.4$ & $32.4 \pm 4.8$ & $<0.001^{\text {१ } ~}$ \\
\hline BMI-SDS & $-0.3 \pm 0.8$ & $3.4 \pm 1.4$ & $3.6 \pm 1.1$ & $<0.001^{9 \neq}$ \\
\hline Waist Circumference (cm) & $71.1 \pm 9.5$ & $103.4 \pm 9.5$ & $105.1 \pm 10.2$ & $<0.001^{1 \neq}$ \\
\hline BF\% & $15.9 \pm 8.7$ & $38.1 \pm 6.5$ & $37.6 \pm 6.9$ & $<0.001^{1 \neq}$ \\
\hline (BF\%-SDS) & $-1.1 \pm 1.2$ & $2.6 \pm 1.1$ & $2.5 \pm 1.0$ & $<0.001^{1 \neq}$ \\
\hline Systolic blood pressure & $105.3 \pm 9.6$ & $118.0 \pm 10.2$ & $126.8 \pm 14.7$ & $<0.001^{1 \neq}$ \\
\hline Diastolic blood pressure & $70.1 \pm 9.1$ & $77.4 \pm 7.4$ & $83.6 \pm 10.1$ & $\begin{array}{l}<0.001^{1 \neq} \\
<0.05^{*}\end{array}$ \\
\hline Fasting glucose, $\mathrm{mg} / \mathrm{dL}$ & $89.2 \pm 7.7$ & $89.0 \pm 8.7$ & $91.4 \pm 9.7$ & NS \\
\hline Fasting insulin, IU/mL & $8.8 \pm 5.3$ & $19.6 \pm 10.2$ & $23.4 \pm 9.5$ & $<0.001^{1 \neq}$ \\
\hline HOMA-IR & $1.9 \pm 1.2$ & $4.3 \pm 2.3$ & $5.3 \pm 2.2$ & $<0.001^{1 \mp}$ \\
\hline Uric Acid & $3.6 \pm 0.8$ & $5.2 \pm 1.3$ & $5.1 \pm 0.9$ & $<0.001^{1 \neq}$ \\
\hline Total cholesterol & $162.7 \pm 28.1$ & $167.5 \pm 33.6$ & $162.9 \pm 22.4$ & NS \\
\hline Triglyceride & $96.1 \pm 60.7$ & $108.0 \pm 47.5$ & $171.0 \pm 73.1$ & $<0.001^{\neq^{*}}$ \\
\hline HDL & $52.4 \pm 11.8$ & $47.1 \pm 6.8$ & $37.6 \pm 6.0$ & $\begin{array}{l}<0.001^{*^{*}} \\
<0.05^{\emptyset}\end{array}$ \\
\hline LDL & $89.5 \pm 23.2$ & $98.4 \pm 28.7$ & $90.7 \pm 22.4$ & NS \\
\hline
\end{tabular}

MS: Metabolic Syndrome; BMI: Body mass indexes; BF\%: percentage of body fat; HOMA-IR: Homeostasis model of insulin resistance; NS: Not significant; "IP Value: Between control group and obese MS (-) group; ${ }^{*} \boldsymbol{P}$ Value: Between control group and obese MS (+) group; 'P Value: Between obese MS (-) group and obese MS (+) group.

Table II: Pearson correlation coefficients between metabolic syndrome risk factors with BF\%-SDS and uric acid levels.

\begin{tabular}{|c|c|c|c|c|}
\hline & \multicolumn{2}{|c|}{ BF\%-SDS } & \multicolumn{2}{|c|}{ Uric Acid } \\
\hline & $r$ & p & $r$ & p \\
\hline BMI & 0.86 & $<0.001$ & 0.50 & $<0.001$ \\
\hline BMI-SDS & 0.86 & $<0.001$ & 0.47 & $<0.001$ \\
\hline Waist Circumference & 0.85 & $<0.001$ & 0.51 & $<0.001$ \\
\hline BF\% & - & - & 0.42 & $<0.001$ \\
\hline BF\%-SDS & - & - & 0.46 & $<0.001$ \\
\hline Systolic blood pressure & 0.52 & $<0.001$ & 0.39 & $<0.001$ \\
\hline Diastolic blood pressure & 0.42 & $<0.001$ & 0.32 & 0.002 \\
\hline Fasting glucose, mg/dL & 0.02 & 0.76 & 0.01 & 0.84 \\
\hline Fasting insulin, IU/mL & 0.52 & $<0.001$ & 0.39 & $<0.001$ \\
\hline HOMA-IR & 0.51 & $<0.001$ & 0.38 & $<0.001$ \\
\hline Uric Acid & 0.48 & $<0.001$ & - & - \\
\hline Total cholesterol & 0.02 & 0.83 & -0.03 & 0.71 \\
\hline Triglyceride & 0.22 & 0.02 & 0.26 & 0.006 \\
\hline HDL & -0.35 & $<0.001$ & -0.42 & $<0.001$ \\
\hline LDL & 0.05 & 0.56 & -0.02 & 0.79 \\
\hline
\end{tabular}


Table III: Multiple regression analysis between BF\%-SDS and MS risk factors.

\begin{tabular}{l|c|c}
\hline \multicolumn{1}{c}{ Variable } & B-Coefficient $\mathbf{( 9 5 \% ~ C l )}$ & p \\
\hline Systolic Blood pressure & $0.026(0.004-0.048)$ & $<0.005$ \\
Waist circumference & $3.44(2.43-4.46)$ & $<0.001$ \\
\hline Uric Acid & $0.24(0.004-0.48)$ & $<0.005$ \\
\hline
\end{tabular}

$(13,29)$. In a study comparing the MS prevalence for s-UA levels among 1370 adolescents aged between 12 and 17 years, Ford et al. (14) showed that the MS frequency is lower than $1 \%$ for the s-UA levels in the first quarter group and $21.1 \%$ for the $\mathrm{s}-\mathrm{UA}$ levels in the fourth quarter group. Some authors advocate that s-UA levels should be added to the MS diagnostic criteria $(29,30)$. However, the causal relationship between uric acid and MS cannot be fully explained. There is a close relationship between the degree of insulin resistance, which is thought to be the main triggering factor among the development of MS components, and s-UA. For instance, medications that improve insulin sensitivity also decrease the level of s-UA (31).

Our study had several limitations. Our sample size was small. Secondly, bioelectric impedance does not enable analysis of the regional body composition in contrast to imaging techniques and DXA. However, we should keep in mind that procedures other than bioelectrical impedance analysis are not yet feasible, and the effect of radiation in this age group is another concern.

In conclusion, total body fat measured via bioelectrical impedance analysis and uric acid had a close relationship with MS components and may be a useful predictive marker for MS diagnosis. Larger comprehensive studies with an increased number of cases in each group are needed to explore this relationship.

\section{REFERENCES}

1. Zimmet P, Alberti KG, Kaufman F, Tajima N, Silink M, Arslanian S, et al. The metabolic syndrome in children and adolescents - an IDF consensus report. Pediatr Diabetes 2007;8:299-306.

2. Rodriguez G, Moreno LA, Blay MG, Blay VA, Fleta J, Sarria A, et al. Body fat measurement in adolescents: Comparison of skinfold thickness equations with dual-energy $\mathrm{X}$-ray absorptiometry. Eur $\mathrm{J}$ Clin Nutr 2005;59:1158-66.

3. Rodriguez G, Moreno LA, Blay MG, Blay VA, Garagorri JM, Sarria $A$, et al. Body composition in adolescents: measurements and metabolic aspects. Int J Obes Relat Metab Disord 2004;(28 Suppl 3):54-58.

4. Lindsay RS, Hanson RL, Roumain J, Ravussin E, Knowler WC, Tataranni PA. Body mass index as a measure of adiposity in children and adolescents: Relationship to adiposity by dual energy x-ray absorptiometry and to cardiovascular risk factors. J Clin Endocrinol Metab 2001;86:4061-7.

5. Daniels SR, Khoury PR, Morrison JA. The utility of body mass index as a measure of body fatness in children and adolescents: Differences by race and gender. Pediatrics 1997;99:804-7.
6. Druet C, Baltakse V, Chevenne D, Dorgeret S, Zaccaria I, Wang Y, et al. Independent effect of visceral adipose tissue on metabolic syndrome in obese adolescents. Horm Res 2008;70:22-8.

7. Despres JP, Moorjani S, Lupien PJ, Tremblay A, Nadeau A, Bouchard C. Regional distribution of body fat, plasma lipoproteins, and cardiovascular disease. Arteriosclerosis 1990;10:497-511.

8. Nguyen-Duy TB, Nichaman MZ, Church TS, Blair SN, Ross R. Visceral fat and liver fat are independent predictors of metabolic risk factors in men. Am J Physiol Endocrinol Metab 2003;284:1065-71.

9. Kim JA, Park HS. Association of abdominal fat distribution and cardiometabolic risk factors among obese Korean adolescents. Diabetes Metab 2008;34:126-30.

10. Kwon JH, Jang HY, Oh MJ, Rho JS, Jung JH, Yum KS, et al. Association of visceral fat and risk factors for metabolic syndrome in children and adolescents. Yonsei Med J 2011;52:39-44.

11. Neovius M, Rossner SM, Vagstrand K, von Hausswolff-Juhlin YL, Hoffstedt J, Ekelund U. Adiposity measures as indicators of metabolic risk factors in adolescents. Obes Facts 2009;2:294-301.

12. Berry CE, Hare JM. Xanthine oxidoreductase and cardiovascular disease: Molecular mechanisms and pathophysiological implications. J Physiol 2004;555:589-606.

13. Ishizaka N, Ishizaka Y, Toda E, Nagai R, Yamakado M. Association between serum uric acid, metabolic syndrome, and carotid atherosclerosis in Japanese individuals. Arterioscler Thromb Vasc Biol 2005;25:1038-44.

14. Ford ES, Li C, Cook S, Choi HK. Serum concentrations of uric acid and the metabolic syndrome among US children and adolescents. Circulation 2007;115:2526-32.

15. Nakagawa T, Hu H, Zharikov S, Tuttle KR, Short RA, Glushakova $O$, et al. A causal role for uric acid in fructose-induced metabolic syndrome. Am J Physiol Renal Physiol 2006;290:625-31.

16. Molnar D, Decsi T, Koletzko B. Reduced antioxidant status in obese children with multimetabolic syndrome. Int J Obes Relat Metab Disord 2004;28:1197-202.

17. Culleton BF, Larson MG, Kannel WB, Levy D. Serum uric acid and risk for cardiovascular disease and death: The Framingham Heart Study. Ann Intern Med 1999;131:7-13.

18. Hatipoglu N, Ozturk A, Mazicioglu MM, Kurtoglu S, Seyhan S, Lokoglu F. Waist circumference percentiles for 7- to 17-year-old Turkish children and adolescents. Eur J Pediatr 2008;167:383-9.

19. Kurtoglu S, Mazicioglu MM, Ozturk A, Hatipoglu N, Cicek B, Ustunbas HB. Body fat reference curves for healthy Turkish children and adolescents. Eur J Pediatr 2010;169:1329-35.

20. Neovius MG, Linne YM, Barkeling BS, Rossner SO. Sensitivity and specificity of classification systems for fatness in adolescents. Am J Clin Nutr 2004;80:597-603.

21. Han JC, Lawlor DA, Kimm SY. Childhood obesity. Lancet 2010;375:1737-48. 
22. Pouliot MC, Despres JP, Lemieux S, Moorjani S, Bouchard C, Tremblay $A$, et al. Waist circumference and abdominal sagittal diameter: Best simple anthropometric indexes of abdominal visceral adipose tissue accumulation and related cardiovascular risk in men and women. Am J Cardiol 1994;73:460-8.

23. Fox K, Peters D, Armstrong N, Sharpe P, Bell M. Abdominal fat deposition in 11-year-old children. Int J Obes Relat Metab Disord 1993;17:11-6.

24. de Ridder CM, de Boer RW, Seidell JC, Nieuwenhoff CM, Jeneson JA, Bakker CJ, et al. Body fat distribution in pubertal girls quantified by magnetic resonance imaging. Int $\mathrm{J}$ Obes Relat Metab Disord 1992;16:443-9.

25. Facchini F, Chen YD, Hollenbeck CB, Reaven GM. Relationship between resistance to insulin-mediated glucose uptake, urinary uric acid clearance, and plasma uric acid concentration. JAMA 1991;266:3008-11.

26. Bedir A, Topbas M, Tanyeri F, Alvur M, Arik N. Leptin might be a regulator of serum uric acid concentrations in humans. Jpn Heart J 2003;44:527-36.
27. Wang DD, Sievenpiper JL, de Souza RJ, Chiavaroli L, Ha V, Cozma $\mathrm{Al}$, et al. The effects of fructose intake on serum uric acid vary among controlled dietary trials. J Nutr 2012;142:916-23.

28. Gao X, Qi L, Qiao N, Choi HK, Curhan G, Tucker KL et al. Intake of added sugar and sugar-sweetened drink and serum uric acid concentration in US men and women. Hypertension 2007;50: 306-12.

29. Leyva F, Godsland IF, Worthington M, Walton C, Stevenson JC. Factors of the metabolic syndrome: Baseline interrelationships in the first follow-up cohort of the HDDRISC Study (HDDRISC-1). Heart Disease and Diabetes Risk Indicators in a Screened Cohort. Arterioscler Thromb Vasc Biol 1998;18:208-14.

30. Tsouli SG, Liberopoulos EN, Mikhailidis DP, Athyros VG, Elisaf MS. Elevated serum uric acid levels in metabolic syndrome: An active component or an innocent bystander? Metabolism 2006;55:1293301.

31. Tsunoda S, Kamide K, Minami J, Kawano Y. Decreases in serum uric acid by amelioration of insulin resistance in overweight hypertensive patients: Effect of a low-energy diet and an insulinsensitizing agent. Am J Hypertens 2002;15:697-701. 